\title{
Synthesis of Large Pore LTL and MOR Zeolites and Use as Adsorbent for The Removal of Heavy Metal and Radioactive Metal Ions in Aqueous Solution
}

\section{Duy Hoai-Phuong Nguyen}

Vietnam National University Ho Chi Minh City

Quang Thanh Le

Vietnam Academy of Science and Technology

Tung Cao Thanh Pham ( $\nabla$ pcttung@ict.vast.vn )

Vietnam Academy of Science and Technology https://orcid.org/0000-0002-4631-481X

Thanh Tu Le

Vietnam National University Ho Chi Minh City

\section{Research Article}

Keywords: Large pore zeolites, porous materials, heavy metal, radioactive, metal adsorption

Posted Date: June 29th, 2021

DOI: https://doi.org/10.21203/rs.3.rs-617526/v1

License: (c) (i) This work is licensed under a Creative Commons Attribution 4.0 International License.

Read Full License 


\section{Synthesis of large pore LTL and MOR zeolites and use as adsorbent for the removal of heavy metal and radioactive metal ions in aqueous solution}

Duy Hoai-Phuong Nguyen ${ }^{\mathrm{a}, \mathrm{b}}$, Quang Thanh Le ${ }^{\mathrm{c}}$, Tung Cao-Thanh Pham ${ }^{\mathrm{c}^{*}}$, Thanh Tu Le $\mathrm{e}^{\mathrm{a}, \mathrm{b}^{*}}$

${ }^{a}$ University of Science, Ho Chi Minh City, Dist.5, 72711, Vietnam.

${ }^{b}$ Vietnam National University, Ho Chi Minh City, Vietnam.

${ }^{c}$ Vietnam Academy of Science and Technology, Institute of Chemical Technology, Ho Chi Minh City, Dist.12, 71515, Vietnam.

Corresponding author

*e-mail: letuthanh@hcmus.edu.vn;

pcttung@ict.vast.vn; Tel: +84-(0)93 6863035; Fax: +84-(0)283 8293889

\section{Acknowledgments}

This work was supported by Vietnam National University, Ho Chi Minh City, Vietnam for project code No. C2018-18-23. We would like to thank Associate Professor Nguyen Van Dong from Faculty of Chemistry, University of Science, VNU-HCMC for supporting the measurement of heavy metal ion. 


\begin{abstract}
Heavy metal and radioactive ions can cause serious environmental problems if 2 they are not completely removed from wastewater as well as in groundwater. In this 3 study, large pore LTL and MOR zeolites were successfully synthesized and used as 4 adsorbent to remove $\mathrm{Pb}^{2+}, \mathrm{Cu}^{2+}, \mathrm{Zn}^{2+}, \mathrm{Cd}^{2+}, \mathrm{Cs}^{+}$and $\mathrm{Sr}^{2+}$ ions in aqueous solution. At low

5 initial concentration (10 ppm), LTL and MOR zeolites effectively removed above metal 6 ions with removal efficiency in the range of 95-99\%. Both zeolites showed high affinity 7 to $\mathrm{Cs}^{+}$and $\mathrm{Pb}^{2+}$ ions with the adsorption capacity of LTL zeolite to $\mathrm{Cs}^{+}$and $\mathrm{Pb}^{2+}$ were $8278.8 \mathrm{mg} / \mathrm{g}$ and $141.4 \mathrm{mg} / \mathrm{g}$, and that of MOR zeolite were $238.8 \mathrm{mg} / \mathrm{g}$ and $178.9 \mathrm{mg} / \mathrm{g}$, 9 respectively. The EDS results showed that $\mathrm{Pb}^{2+}$ ions from the aqueous solution were 10 exchanged with exchangeable $\mathrm{Na}^{+}$ions in MOR zeolite and $\mathrm{K}^{+}$ions in LTL zeolite. The 11 pseudo-second-order kinetic model and Langmuir isotherm model fitted better to 12 experiment data on the adsorption of metal ions on both LTL and MOR zeolite. This 13 result revealed that the adsorption of these metal ions on LTL and MOR zeolite was 14 monolayer chemisorption. The equilibrium adsorption results showed that the 15 microstructure of zeolite significantly affected the adsorption capacity of LTL and MOR 16 zeolite on removal of tested metal ions.
\end{abstract}

\title{
Keywords
}

Large pore zeolites, porous materials, heavy metal, radioactive, metal adsorption 


\section{Introduction}

Heavy metal pollution is one of the most concerning issues in the balance between industrialization and environment protection. Heavy metal contamination usually comes from heavy industries and manufacturers such as mining, steel, metal plating, tanneries,

4 battery production (Sprynskyy et al. 2006). Heavy metal ions such as lead $\left(\mathrm{Pb}^{2+}\right)$, copper

$5\left(\mathrm{Cu}^{2+}\right)$, zinc $\left(\mathrm{Zn}^{2+}\right)$, cadmium $\left(\mathrm{Cd}^{2+}\right)$ are non-biodegradable, highly water-soluble. They permeate into and accumulate for long time in soil, pollute the surface water and groundwater. Due to the bioaccumulation, they can absorb and accumulate in food, living organisms, human bodies and cause serious health effects (Azimi et al. 2017). Besides, radioactive contaminants in nuclear facilities waste stream are also an important environmental concern. Cesium (Cs) and strontium (Sr) are the most abundant radionuclides in nuclear fission products. The radioactive $\mathrm{Cs}$ and $\mathrm{Sr}$ are very dangerous to human health due to their relatively long half-life, about 30 years. The environmental problem caused by these radioactive isotopes will last for a very long time (El-Kamash 2008).

Several methods and technologies have been developed to eliminate heavy metals and radioactive metals in waste water prior to discharge. Some of the common methods are electro-coagulation, electro-flotation, electrodeposition, chemical precipitation, ion exchange, adsorption, membrane filtration, reverse osmosis, and advance oxidation (Azimi et al. 2017). Among these methods, adsorption is one of the most popular techniques due to its simplicity and efficiency.

Zeolite is a microporous material with a well-defined framework and microstructure. Depending on composition and microstructure, zeolites have different micro-properties and applications (Lobo 2003). In adsorption application, the pure silica zeolite with hydrophobic channel system showed high capture capacity to radioactive iodine (Pham et al. 2016). Some synthetic zeolites were reported with very high selectivity in removal of radioactive metal ions (Datta et al. 2014, 2019). Aluminosilicate zeolites are suitable for removal of metal ions from water due to their high porsosity, hydrophilic channel system, high stability, high ion exchange capacity, and their ability to generate non-toxic counter exchanged-ion (Davis 2014, Zendelska et al. 2014). Natural zeolites have been widely studied for the removal of metal ions in aqueous solution. Among natural zeolites, clinoptilolite and mordenite were the most concerned. They were used as adsorbent for the removal of heavy metal ions such as $\mathrm{Pb}^{2+}, \mathrm{Cu}^{2+}, \mathrm{Zn}^{2+}, \mathrm{Co}^{2+}$, $\mathrm{Mn}^{2+}$ in aqueous solution (Sprynskyy et al. 2006, Zendelska et al. 2014, Erdem et al. 2004, Günay et al. 2007, Wang et al. 2008, Mihaly-Cozmuta et al. 2014, Aghel et al. 2020, Galletti et al. 2020). Clinoptilolite and mordenite natural zeolites were also used for 
decontamination of radioactive ions as $\mathrm{Cs}^{+}, \mathrm{Sr}^{2+}, \mathrm{Co}^{2+}$ (Moattar and Hayeripour 2004,

2 Prajitno et al. 2021). Clinoptilolite is found naturally in the form of rock. It contains several impurity phases such as quartz, smectite, mica (Wang et al. 2008). Therefore, the adsorption capacity of natural zeolites is highly different from reported works, varied from a few to hundreds of $\mathrm{mg} / \mathrm{g}$, depending on the sources of the zeolites (Sprynskyy et al. 2006, Erdem et al. 2004, Wang et al. 2008). Synthetic zeolites have been used in catalytic reaction, gas separation, sensing material, wastewater treatment (Kwon et al. 2020). Among various zeolite frameworks, Linda Type A (LTA) zeolite has the lowest silicon-aluminum ratio, $\mathrm{Si} / \mathrm{Al}$ of $1-2$, leading to the highest cation exchange capacity (Collins et al. 2020). Synthetic LTA zeolite was used as adsorbent material for the removal of heavy metal and radioactive metal ions from aqueous solution (El-Kamash et al. 2005, Ibrahim et al. 2010, Tashauoei et al. 2010, Lu et al. 2016, Shen et al. 2017,

12 Hong et al. 2019, Li et al. 2020). Despite its remarkable cation exchange capacity, the small-pore of LTA zeolite, with the pore diameter of $4.1 \AA$, may affect their metal ions removal efficiency (Kwon et al. 2020).

Linda Type L (LTL) and mordenite (MOR) zeolites are two of the most widely used large-pore synthetic zeolites. The crystal structure of LTL zeolite consists of a onedimensional channel with aperture of about 7.1 A running across the $c$-axis (McCusker et al. 2007), and the $\mathrm{Si} / \mathrm{Al}$ ratio ranging of 3.0-6.0 (typically 3.0). LTL zeolite is mostly used as catalyst (Calzaferri 2020), host for accommodation of organic dye as optical material (Calzaferri 2020, Fois et al. 2013). MOR zeolite is a two-dimensional channel system with $\mathrm{Si} / \mathrm{Al}$ ratio in the range of 4-12. The framework of MOR zeolite contains an elliptical pore channel with pore size of $6.7 \times 7.0 \AA$ running across the $c$-axis and another channel running across the $b$-axis with pore diameter of $2.6 \times 5.7 \AA$ (McCusker et al. 2007). MOR zeolite has been used in catalytic reactions, semiconductors, chemical sensors, separation of gas or liquid mixture, and solid adsorbent (Hincapie et al. 2004).

We report here the synthesis of large pore LTL and MOR zeolite by conventional hydrothermal reaction and use of synthesized zeolites as adsorbent for removal of heavy metal ions including $\mathrm{Cu}^{2+}, \mathrm{Cd}^{2+}, \mathrm{Pb}^{2+}, \mathrm{Zn}^{2+}$, and radioactive ions including $\mathrm{Cs}^{+}, \mathrm{Sr}^{2+}$ in aqueous solution. The sorption characteristics including adsorption kinetic, adsorption equilibrium and sorption models were investigated.

\section{Materials and methods}

\section{Materials}

Aluminum hydroxide $\left(\mathrm{Al}(\mathrm{OH})_{3}, 76.5 \%\right.$, Alfa Aesar), Potassium hydroxide $(\mathrm{KOH}$, $85 \%$, Merck), Sodium aluminate $\left(\mathrm{NaAlO}_{2}, 99 \%\right.$, Alfa Aesar), Sodium hydroxide $(\mathrm{NaOH}$, 99\%, Merck), Ludox-AS40 ( $\mathrm{SiO}_{2}, 40 \%$, Sigma Aldrich) were used for the synthesis of 
LTL and MOR zeolites. Cadmium acetate $\left(\left(\mathrm{CH}_{3} \mathrm{COO}\right)_{2} \mathrm{Cd} \cdot 2 \mathrm{H}_{2} \mathrm{O}\right.$, >99\%, Xilong

2 Scientific), Copper(II)nitrate $\left(\mathrm{Cu}\left(\mathrm{NO}_{3}\right)_{2} \cdot 2 \mathrm{H}_{2} \mathrm{O},>99 \%\right.$, Xilong Scientific), Lead(II)nitrate

$3\left(\mathrm{~Pb}\left(\mathrm{NO}_{3}\right)_{2},>99 \%\right.$, Xilong Scientific), Zinc sulfate $\left(\mathrm{ZnSO}_{4} .7 \mathrm{H}_{2} \mathrm{O},>99 \%\right.$, Xilong

4 Scientific), Caesium nitrate $\left(\mathrm{CsNO}_{3},>99 \%\right.$, Xilong Scientific), Strontium nitrate

$5 \quad\left(\mathrm{Sr}\left(\mathrm{NO}_{3}\right)_{2},>99 \%\right.$, Xilong Scientific) were used in metal removal experiments. All

6 chemicals and reagents in this study were used as received without further purification.

Synthesis of LTL and MOR zeolite

LTL zeolite was synthesized from a gel composed of $\mathrm{KOH}, \mathrm{Al}(\mathrm{OH})_{3}$, LudoxAS40 and deionized water (DIW) with the molar ratio in term of $\mathrm{Al}_{2} \mathrm{O}_{3} / \mathrm{K}_{2} \mathrm{O} / \mathrm{SiO}_{2} / \mathrm{H}_{2} \mathrm{O}$ was 1.2/3.0/9.83/165. The reaction gel was prepared by adding $1.32 \mathrm{~g}$ of $\mathrm{KOH}$ and $6.62 \mathrm{~g}$ of DIW in a plastic beaker with stirring until completely dissolved, then $0.82 \mathrm{~g}$ of $\mathrm{Al}(\mathrm{OH})_{3}$ was added. After stirring for 30 minutes at room temperature, $4.82 \mathrm{~g}$ of LudoxAS40 was added dropwise into the solution to create a white gel. The gel was aged for 3.5 hours at room temperature with vigorous stirring. The reaction gel was then transferred into a Teflon-lined autoclave. The hydrothermal reaction was carried out in a conventional oven at $170^{\circ} \mathrm{C}$ for 3 days.

MOR zeolite was synthesized from a gel composed of $\mathrm{NaOH}, \mathrm{NaAlO}_{2}$, LudoxAS40 and DIW with the molar ratio in term of $\mathrm{Na}_{2} \mathrm{O} / \mathrm{Al}_{2} \mathrm{O}_{3} / \mathrm{SiO}_{2} / \mathrm{H}_{2} \mathrm{O}$ was 4.5/1/19/294. The synthesis gel was prepared by adding $0.63 \mathrm{~g}$ of $\mathrm{NaOH}$ and $7.8 \mathrm{~g}$ of DIW in a plastic beaker with stirring until completely dissolved, then $0.37 \mathrm{~g}$ of $\mathrm{NaAlO}_{2}$ was added. The mixture was stirred for 30 minutes to create a homogenous white color mixture. After that, $6.3 \mathrm{~g}$ of Ludox-AS40 was added dropwise into the mixture to obtain a white gel. The gel was aged for 2 hours at room temperature with vigorous stirring. The synthesis gel was then transferred into a Teflon-lined autoclave. The hydrothermal reaction was carried out in a conventional oven at $175^{\circ} \mathrm{C}$ for 4 days.

\section{Sorption studies}

\section{Kinetic study}

Kinetic adsorption of metal ions on zeolite was investigated by adding $0.1 \mathrm{~g}$ of LTL/MOR zeolite and $150 \mathrm{~mL}$ solution containing $50 \mathrm{ppm}$ of single metal ions as $\mathrm{Cu}^{2+}$, $\mathrm{Cd}^{2+}, \mathrm{Pb}^{2+}, \mathrm{Zn}^{2+}, \mathrm{Cs}^{+}, \mathrm{Sr}^{2+}$ into a glass beaker. The $\mathrm{pH}$ of the solution was about 6.0 - 7.0. The mixture was then stirred at room temperature. After certain periods of time, $2 \mathrm{~mL}$ of the aliquot was collected whilst the mixture was kept stirring to maintain the initial ratio of adsorbent and solution. Zeolite adsorbent in the collected sample was separated by centrifugation, and the concentration of metal ions in the solution was measured. 
The adsorption capacity and the removal efficiency of zeolite for metal ions were

2 calculated using the equation (1) and (2), respectively:

$$
\begin{gathered}
q=\frac{\left(C_{0}-C_{t}\right) x V}{m} \\
H=\frac{\left(C_{0}-C_{t}\right)}{C_{0}}
\end{gathered}
$$

3 where $t$ (minute) was time length of the adsorption test, $\mathrm{C}_{0}(\mathrm{ppm})$ and $\mathrm{C}_{\mathrm{t}}(\mathrm{ppm})$ were the 4 concentrations of metal ions in the initial solution and the solution at time $t$, respectively, $5 \mathrm{~m}(\mathrm{~g})$ was the weight of zeolite adsorbent, $\mathrm{V}(\mathrm{L})$ was the volume of the solution, $\mathrm{q}(\mathrm{mg} / \mathrm{g})$ 6 was the adsorption capacity and $\mathrm{H}(\%)$ was the removal efficiency.

\section{Equilibrium study}

Batch adsorption experiment was carried out at room temperature in $250 \mathrm{~mL}$ glass beaker with using $0.1 \mathrm{~g}$ of LTL/MOR zeolite and $150 \mathrm{~mL}$ of metal salt solution containing single metal ions as $\mathrm{Cu}^{2+}, \mathrm{Cd}^{2+}, \mathrm{Pb}^{2+}, \mathrm{Zn}^{2+}, \mathrm{Cs}^{+}, \mathrm{Sr}^{2+}$. The initial concentration of metal ions was varied from 10 to $600 \mathrm{ppm}$. The $\mathrm{pH}$ of the solution was about 6.0-7.0. The mixture was stirred for 2 hours (in case of LTL zeolite) or 3 hours (in case of MOR zeolite) for saturated adsorption. After adsorption time, zeolite was removed from the solution by centrifugation, and concentration of metal ions remaining in solution was determined. The adsorption capacity and removal efficiency were calculated as described above.

\section{Characterization methods}

Scanning electron microscopy (SEM) analysis was obtained from scanning electron microscope JEOL JSM-6400 operating at acceleration voltage of $5 \mathrm{kV}$. Powder X-ray diffraction (XRD) patterns were obtained using a Bruker D8 Advance powder Xray diffractometer operating at $40 \mathrm{kV}$ and $40 \mathrm{~mA}$ with $\mathrm{Cu}-\mathrm{K} \alpha$ radiation. Energy dispersive X-ray (EDS) measurements were obtained from Hitachi FESEM S4800 and Horiba EDX H-7593. The concentrations of heavy metal ions were measured using a flame-atomic absorption spectrophotometry (Shimadzu AA-6300) with an air-acetylene flame. Cadmium, copper, cesium, lead, strontium and zinc hollow cathode lamps were used as radiation source with wavelengths of $228.8 \mathrm{~nm}, 852.1 \mathrm{~nm}, 324.8 \mathrm{~nm}, 283.3 \mathrm{~nm}$, $460.7 \mathrm{~nm}$, respectively.

\section{Result and discussion}

\section{Characterization of synthesized zeolites}


We first synthesized two types of large pore LTL and MOR zeolite by conventional hydrothermal reaction as described in detail in the experiment section, and their characteristics were shown in Fig. 1. The typical hexagonal prism crystals of LTL zeolite were obtained by scanning electron microscope (SEM) as shown in Fig. 1a. The $\mathrm{x}$-ray diffraction pattern (XRD) in Fig. 1b confirmed the main LTL zeolite structure in the synthesized product. Similarly, MOR zeolite with average crystal size of $20 \mu \mathrm{m}$ and prismatic morphology was synthesized and shown in Fig. 1c. The XRD pattern showed the peaks of MOR structure (Fig. 1d). The relatively high intensity diffraction peaks are consistent with the large crystal, and reveal the high crystallinity of obtained material. The Si/Al ratio obtained by energy dispersive spectroscopy (EDS) measurements were 2.97 for LTL and 6.91 for MOR zeolite, respectively. The above synthesized LTL and MOR zeolites were used as adsorbent for heavy metal removal studies without further modification.

\section{Kinetic studies}

In this work, the effect of adsorption time to the adsorption of metal ions on LTL zeolite was shown in Fig. 2. The adsorption process of all metal ions on LTL zeolite was relatively fast. Within 15 minutes, the equilibrium state was reached (except $\mathrm{Sr}^{2+}$, the equilibrium was reached at 60 minutes). The pseudo-first-order and pseudo-second-order models of the metal ions adsorption on LTL zeolite were also presented in Fig. 2. The parameters of these models are shown in Table 1 . The correlation coefficients $R^{2}$ of pseudo-second-order model (0.99-1) were much higher than that of the pseudo-first-order model case (0.21-0.79), and the simulated equilibrium adsorption capacity calculated from pseudo-second-order model was approximate to the experimental data (Fig. 2a-f). Therefore, the pseudo-second-order model was more suitable to describe the adsorption kinetic of metal ions on LTL zeolite (Fig. 2g,h). The obtained result revealed that the pseudo-second-order sorption mechanism was predominant, and the adsorption rate of metal ions on LTL zeolite occurred following the chemisorption process (El-Kamash et al. 2005).

Additionally, the adsorption of metal ions on MOR zeolite with different periods of time was shown in Fig. 3. The adsorption process of $\mathrm{Pb}^{2+}$ and $\mathrm{Cs}^{+}$ions on MOR zeolite occurred relatively faster than that of the remaining metal ions (Fig. 3a,b). The equilibrium state achieved within 10 minutes, whilst the adsorption process and the loading amount of $\mathrm{Cu}^{2+}, \mathrm{Cd}^{2+}, \mathrm{Zn}^{2+}, \mathrm{Sr}^{2+}$ metal ions on MOR zeolite kept increasing slowly until 180 minutes of adsorption experiment without getting equilibrium state (Fig. $3 \mathrm{c}-\mathrm{f})$. The pseudo-first-order and pseudo-second-order models of the metal ions adsorption on MOR zeolite were plotted in Fig. 3a-f, and the parameters of these models were presented in Table 2. Similar to the LTL zeolite case, the pseudo-second-order 
model fitted with higher fitting degree to experiment data on kinetic adsorption of metal ions on MOR zeolite (Fig. 3g,h). The chemisorption was the main process governing the sorption rate of tested metal ions on MOR zeolite.

The calculated pseudo-second-order model adsorption rate constants $\mathrm{k}_{2}$ of metal ions on LTL, MOR zeolite were shown in Table 3. The adsorption rate constants of tested metal ions on LTL zeolite were higher than the obtained values in MOR zeolite case. In our study, there are two factors that might affect to this result, including the $\mathrm{Si} / \mathrm{Al}$ ratio and crystal size of two zeolites. The LTL zeolite with Si/Al ratio of 2.97 contained a higher exchangeable site that increased the ion exchange rate. Besides, the crystal size of MOR zeolite is larger than that of LTL crystal, which might decrease the diffusion rate of ion in MOR zeolite as observed in other reported works (Kwon et al. 2020).

\section{Equilibrium studies}

The metal ions adsorption in terms of removal efficiency and adsorption capacity were shown in Fig. 4. The removal efficiency of $\mathrm{Cu}^{2+}, \mathrm{Cd}^{2+}, \mathrm{Pb}^{2+}, \mathrm{Zn}^{2+}, \mathrm{Cs}^{+}, \mathrm{Sr}^{2+}$ on LTL and MOR zeolite at initial concentrations ranged from 10-600 ppm were shown in Fig. 4a and Fig. 4c, respectively. At the initial concentration of $10 \mathrm{ppm}$, LTL zeolite effectively removed $\mathrm{Cd}^{2+}, \mathrm{Pb}^{2+}, \mathrm{Sr}^{2+}$ and $\mathrm{Cs}^{+}$with the efficiency of 96, 97.1, 95.4 and 97.6\% respectively. At the same time, the removal efficiency of MOR zeolite to $\mathrm{Cu}^{2+}$, $\mathrm{Cd}^{2+}, \mathrm{Pb}^{2+}, \mathrm{Sr}^{2+}$ and $\mathrm{Cs}^{+}$was $98.2,98.2,96.9,94.9$ and $99 \%$, respectively. These results revealed that both LTL and MOR zeolites were able to effectively remove these metal ions at low concentration in water. The removal efficiency of both zeolites dramatically decreased with increasing concentration of all metal ions. However, this is a relative number based on the concentration of metal ions before and after adsorption. In high concentration condition, the adsorption capacity is a more important value.

The adsorption capacity of $\mathrm{Cu}^{2+}, \mathrm{Cd}^{2+}, \mathrm{Pb}^{2+}, \mathrm{Zn}^{2+}, \mathrm{Cs}^{+}, \mathrm{Sr}^{2+}$ ions on LTL and MOR zeolites at different initial concentrations ranging from $10-600 \mathrm{ppm}$ were presented in Fig. 4b and Fig. 4d, respectively. We observed that in almost all cases of tested metal ions, the adsorption capacity of both LTL and MOR zeolites in removal of metal ions increased with increasing concentration of metal ions. The same result was reported by the previous study on the adsorption of $\mathrm{Zn}^{2+}$ in natural zeolite. The adsorption capacity of $\mathrm{Zn}^{2+}$ increased with the increase of initial concentration until the saturation point reached. At that point, the further increase of the metal ions concentration would not result in any significant change in adsorption capacity. The increase of $\mathrm{Zn}^{2+}$ amount created the concentration gradient and driving force to uptake $\mathrm{Zn}^{2+}$ to adsorbent, which was responsible to overcome the mass transfer resistance associated with the adsorption of metal ions from solution by zeolite (Zendelska et al. 2014). 
In our study, the saturated point of the adsorption of $\mathrm{Cu}^{2+}, \mathrm{Cd}^{2+}, \mathrm{Zn}^{2+}, \mathrm{Sr}^{2+}$ on LTL zeolite was established at the initial metal ions concentration of $50 \mathrm{ppm}$. The further increased concentration to $100 \mathrm{ppm}$ led to a slight increase in the uptake capacity, but it was not significant. The maximum obtained values in adsorption capacity were 28.3, 43.9, 23.1 and $34.6 \mathrm{mg} / \mathrm{g}$ for $\mathrm{Cu}^{2+}, \mathrm{Cd}^{2+}, \mathrm{Zn}^{2+}$ and $\mathrm{Sr}^{2+}$, respectively. In the adsorption of $\mathrm{Pb}^{2+}$ and $\mathrm{Cs}^{+}$metal ions in LTL zeolite, the saturated points were obtained at initial concentration of $100 \mathrm{ppm}$ and $450 \mathrm{ppm}$ with the highest adsorption capacity of 141.4 $\mathrm{mg} / \mathrm{g}$ and $278.8 \mathrm{mg} / \mathrm{g}$, respectively. In the case of $\mathrm{Pb}^{2+}$ ions, the uptake capacity of LTL zeolite was almost unchanged with further increase in solution concentration. However, the adsorption capacity of LTL zeolite for both $\mathrm{Cs}^{+}$and $\mathrm{Pb}^{2+}$ ions decreased as the initial concentration increased to $600 \mathrm{ppm}$ (Fig. 4b). The obtained result might be due to the microstructure and the affinity of LTL zeolite to $\mathrm{Cs}^{+}$and $\mathrm{Pb}^{2+}$ in the adsorption of these metals ions. It was known that the metal ion uptake by zeolite adsorbent occurred by the combination of ion-exchange and adsorption process. Metal ions had to move to the zeolite surface and the pore windows. In the next state, metal ions migrated and diffused through the channel systems to ion-exchange sites and replaced the exchangeable ions (Erdem et al. 2004). In this study, LTL zeolite is a large pore and one-dimension channel system running along the $c$-axis of cylindrical type crystal. In addition, the as-synthesized LTL with $\mathrm{Si} / \mathrm{Al}$ ratio of 2.97 was relatively low. It created a high concentration of ionexchange sites in the framework. Due to these microstructure properties, at high concentration of metal ions containing high density of metal ions in solution, metal ions rapidly contacted and occupied the exchangeable sites in the channels near the crystal surface. As a result, the first occupied ions blocked the channel window and prevented the further diffusion of metal ions in the aqueous solution into the LTL zeolite channel, resulting in decrease of adsorption capacity.

In comparison, in this study the as-synthesized MOR zeolite had Si/Al ratio of 6.91 and 2-dimensional channel system. The adsorption of metal ions occurred relatively slower. The adsorption of $\mathrm{Cu}^{2+}$ and $\mathrm{Sr}^{2+}$ ions reached a saturated point at initial concentration of 50 and $150 \mathrm{ppm}$ and the highest adsorption capacity was 41.3 and 83.3 $\mathrm{mg} / \mathrm{g}$, respectively. With continuously increasing the concentration of metal ions to 600 ppm, the adsorption of $\mathrm{Zn}^{2+}, \mathrm{Cd}^{2+}, \mathrm{Pb}^{2+}$ on MOR zeolite was saturated. The maximum

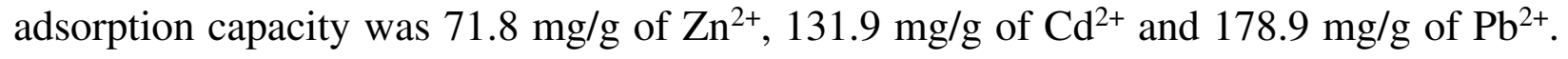
The uptake of $\mathrm{Cs}^{+}$ions in MOR zeolite in this study has not reached a saturated point at this state. The uptake capacity gradually increased with increasing the initial concentration of $\mathrm{Cs}^{+}$ions in solution (Fig. 4d). The adsorption capacity obtained at initial concentration of $600 \mathrm{ppm}$ was $238.8 \mathrm{mg} / \mathrm{g}$ of $\mathrm{Cs}^{+}$which is lower than the highest adsorption capacity of LTL zeolite to $\mathrm{Cs}^{+}$. 
Interestingly, we observed in the case of $\mathrm{Pb}^{2+}$ adsorption in both LTL and MOR zeolites, the highest uptake amount of $\mathrm{Pb}^{2+}$ to LTL zeolite was $141 \mathrm{mg} / \mathrm{g}$ corresponding to $85 \%$ compared to that of MOR zeolite $(179 \mathrm{mg} / \mathrm{g})$ although the ion exchange site in

$4 \quad$ LTL zeolite was almost twice to MOR zeolite. We conducted the EDS measurement on 5 the $\mathrm{Pb}^{2+}$ saturated adsorbed on both zeolites and found that $60 \%$ of exchangeable sites in LTL zeolite remained (4.74\% in 7.99\%) whilst all $\mathrm{Na}^{+}$in exchange sites were replaced by $\mathrm{Pb}^{2+}$ in MOR zeolite $(3.86 \%)$ as shown in Table 4. This obtained result is consistent with the adsorption capacity curves for $\mathrm{Pb}^{2+}$ ions in Figure $4 \mathrm{~b}$ and Figure $4 \mathrm{~d}$. And it also revealed that the microstructure of zeolite in this study strongly affected metal ion uptake.

We observed that the adsorption capacities of both LTL and MOR zeolite to $\mathrm{Cs}^{+}$ and $\mathrm{Pb}^{2+}$ ions were relatively higher compared to the result obtained from the remaining metal ions. These results might be due to the effect of ionic radius, hydrated radius and hydration energy of the metal ions to the adsorption process. It was reported that, the adsorption of metal ions to microporous materials depended on the hydrated radius and hydration energy of metal ions. In fact, in a solution with $\mathrm{pH}$ value at about 6.5 or lower, metal ions existed as a hydrated state. As a result, the ions with smaller ionic radius could closely attack to the adsorbent surface and easily enter the channels of the adsorbent. Furthermore, the low hydration energy ions could easily be dehydrated and shrink in size for better adsorption (Sounthararajah et al. 2015). In our study, $\mathrm{Cs}^{+}$and $\mathrm{Pb}^{2+}$ ions have hydrated radius smaller than the pore diameter of LTL and MOR zeolite beside the lower hydrated energy compared to that of remaining ions as listed in Table 5. These factors responded to the experiment result that LTL and MOR zeolite showed higher adsorption capacity to $\mathrm{Cs}^{+}$and $\mathrm{Pb}^{2+}$ metal ions. The highest hydration energy of $\mathrm{Cu}^{2+}$ and $\mathrm{Zn}^{2+}$ could also relate to their low adsorption capacity on both zeolites.

\section{Sorption modeling}

Kinetic model: The adsorption kinetic was modelled by applying pseudo-firstorder and pseudo-second-order rate models. The Lagergren first-order rate model can be described as equation (3) (Ho and McKay 1999b)

$$
\log \left(q_{e}-q_{t}\right)=\log \left(q_{e}\right)-\frac{k_{1}}{2.303} t
$$

The Lagergren second-order rate model can be described as equation (4)

$$
\frac{t}{q_{t}}=\frac{1}{k_{2} q_{e}^{2}}+\frac{t}{q_{e}}
$$

where $\mathrm{q}_{\mathrm{t}}(\mathrm{mg} / \mathrm{g})$ is the amount of adsorbed metal ions per unit weight of zeolite at time " $\mathrm{t}$ " ( $\mathrm{min}), \mathrm{q}_{\mathrm{e}}(\mathrm{mg} / \mathrm{g})$ is the amount of adsorbed metal ions at equilibrium, $\mathrm{k}_{1}(1 / \mathrm{min})$ is the 
equilibrium rate constant of pseudo-first sorption, calculated from the slope of the linear

2 regression equation of $\log \left(\mathrm{q}_{\mathrm{e}}-\mathrm{q}_{\mathrm{t}}\right)$ on $\log \left(\mathrm{q}_{\mathrm{e}}\right), \mathrm{k}_{2}(\mathrm{~g} / \mathrm{mg} \cdot \mathrm{min})$ is the equilibrium rate constant

3 of pseudo-second sorption, calculated from the intercept of the linear regression equation

4 of $t / q_{t}$ on $t / q_{e}$. The fitted degree of the isotherm and kinetic models to experimental data

5 was investigated by the correlation coefficient $R^{2}$.

Isotherm model: The equilibrium metal adsorption data was simulated with the Langmuir and Freundlich models. Langmuir sorption isotherm bases on the monolayer coverage of the sorbent surface and assumes that sorption occurs at specific homogenous sorption sites. All the sorption sites are energetically identical and intermolecular forces decrease rapidly with the distance from the sorption surface (El-Kamash 2008).

The Langmuir model can be described as equation (5) (El-Kamash 2008)

$$
\frac{C_{e}}{q_{e}}=\frac{1}{Q^{0} K_{L}}+\frac{C_{e}}{Q^{0}}
$$

where $\mathrm{q}_{\mathrm{e}}(\mathrm{mg} / \mathrm{g})$ is the amount of metal ions adsorbed by unit weight of zeolite, $\mathrm{C}_{\mathrm{e}}(\mathrm{mg} / \mathrm{L})$ is the equilibrium concentration of metal ions in the solution, $\mathrm{Q}^{0}(\mathrm{mg} / \mathrm{g})$ is the monolayer adsorption capacity and $\mathrm{K}_{\mathrm{L}}$ is the Langmuir constant related to the free energy of adsorption. $\mathrm{Q}^{0}$ and $\mathrm{K}_{\mathrm{L}}$ are calculated from the slope and the intercept of the linear regression equation of $\mathrm{C}_{\mathrm{e}} / \mathrm{q}_{\mathrm{e}}$ on $\mathrm{C}_{\mathrm{e}}$.

The characteristic of the Langmuir isotherm model is expressed by the equilibrium parameter $\mathrm{R}_{\mathrm{L}}$

$$
R_{L}=\frac{1}{1+K_{L} C_{0}}
$$

where $\mathrm{C}_{0}$ is the highest initial metal ions concentration $(\mathrm{mg} / \mathrm{L})$. The value of $\mathrm{R}_{\mathrm{L}}$ indicates the type of isotherm adsorption to be irreversible $\left(\mathrm{R}_{\mathrm{L}}=0\right)$, favorable $\left(0<\mathrm{R}_{\mathrm{L}}<1\right)$, linear $\left(\mathrm{R}_{\mathrm{L}}=1\right)$, or unfavorable $\left(\mathrm{R}_{\mathrm{L}}>1\right)$ (El-Kamash 2008).

The Freundlich isotherm model describes the multilayer sorption on heterogeneous surfaces. This isotherm expresses the surface heterogeneity and the exponential distribution of active sites and their energy (El-Kamash 2008). The Freundlich model can be described as equation (7)

$$
\log \left(q_{e}\right)=\log \left(K_{F}\right)+\frac{1}{n} \log \left(C_{e}\right)
$$

where $\mathrm{q}_{\mathrm{e}}(\mathrm{mg} / \mathrm{g})$ is the amount of adsorbed metal ions per unit weight of zeolite, $\mathrm{C}_{\mathrm{e}}$ $(\mathrm{mg} / \mathrm{L})$ is the equilibrium concentration of metal ions in the solution, $\mathrm{K}_{\mathrm{F}}$ is Freundlich 
constant indicating the relative sorption capacity of adsorbent, and $1 / \mathrm{n}$ is the constant

2 indicating the intensity of the sorption process. $\mathrm{K}_{\mathrm{F}}$ and $\mathrm{n}$ are calculated from the slope

3 and the intercept of the linear regression equation of $\log \left(\mathrm{q}_{\mathrm{e}}\right)$ on $\log \left(\mathrm{C}_{\mathrm{e}}\right)$ (El-Kamash 4 2008).

The adsorption isotherm modelling of metal ions on LTL and MOR zeolites were 6 plotted in Fig. 5. The obtained result showed that the adsorption of tested metal ions 7 fitted to Langmuir model with higher fitting degree compared to Freundlich model as 8 shown in Fig. 5a,c and Fig. 5b,d, respectively and the correlation coefficients $\mathrm{R}^{2}$ of these 9 equations in Table 6. The monolayer adsorption capacity $\mathrm{Q}^{0}$ values calculated from 10 Langmuir model (Table 6) were relevant to that obtained from experimental data. The results revealed that the adsorption of metal ions on both LTL and MOR zeolites were monolayer and chemical interaction to homogenous adsorption sites. The values of equilibrium parameter $\mathrm{R}_{\mathrm{L}}$ for the adsorption of all metal ions on both zeolites were between 0 and 1 (Table 6), indicating the favorable adsorption of metal ions on these zeolites.

\section{Conclusion}

We have reported herein the synthesis of two large pore zeolites as LTL and MOR zeolite by conventional hydrothermal reaction. The as-synthesized zeolites were used to adsorb heavy metal ions including $\mathrm{Cu}^{2+}, \mathrm{Cd}^{2+}, \mathrm{Pb}^{2+}, \mathrm{Zn}^{2+}$ and radioactive ions as $\mathrm{Cs}^{+}$and $\mathrm{Sr}^{2+}$. At low concentration of metal ions, LTL and MOR showed efficient removal of the tested metal ions. In solution with high concentration of metal ions, the adsorption kinetic followed the pseudo-second-order model indicating the chemisorption process of metal ions on both LTL and MOR zeolites. The results, fitted well to the Langmuir isotherm model, revealed the monolayer adsorption on homogenous surfaces of LTL and MOR zeolite. The equilibrium adsorption results showed that the microstructure of zeolite significantly affected the adsorption capacity of LTL and MOR zeolite on removal of tested metal ions. Both LTL and MOR showed highest adsorption capacity for $\mathrm{Cs}^{+}$and $27 \mathrm{~Pb}^{2+}$ metal ions. 


\section{Declarations}

1 Ethics approval and consent to participate: Not applicable.

2 Consent for publication: Not applicable.

3 Availability of data and materials: All data generated or analysed during this study are

4 included in this published article.

5 Financial interests: The authors declare they have no financial interests.

6 Competing interests: The authors declare that they have no competing interests.

7 Funding: This work was supported by Vietnam National University, Ho Chi Minh City,

8 Vietnam for project code No. C2018-18-23.

9 Authors' contributions: D.H-P.N designed and conducted experiments on zeolite 10 synthesis, metal adsorption, and manuscript preparation. Q.T.L carried out the material 11 characterization. T.C-T.P, T.T.L designed experiments, supervisor, and project 12 administration, prepared-wrote and edited the manuscript. 


\section{References}

Aghel B, Mohadesi M, Gouran A, Razmegir MH (2020) Use of Modified Iranian Clinoptilolite Zeolite for Cadmium and Lead Removal from Oil Refinery Wastewater. Int J Environ Sci Technol. https://doi.org/10.1007/s13762-019-02466-5

Azimi A, Azari A, Rezakazemi M, Ansarpour M (2017) Removal of Heavy Metals from Industrial Wastewaters: A Review. ChemBioEng Rev 4:37-59. https://doi.org/10.1002/cben.201600010

Calzaferri G (2020) Nanochannels of Zeolite L. In: Martínez-Martínez V, López Arbeloa F (eds) Dyes and Photoactive Molecules in Microporous Systems. Springer International Publishing, Cham, pp 48-49.

Collins F, Rozhkovskaya A, Outram JG, Millar GJ (2020) A Critical Review of Waste Resources, Synthesis, and Applications for Zeolite LTA. Microporous Mesoporous Mater 291:109667. https://doi.org/10.1016/j.micromeso.2019.109667

Datta SJ, Moon WK, Choi DY, Hwang IC, Yoon KB (2014) A Novel Vanadosilicate with Hexadeca-Coordinated $\mathrm{Cs}^{+}$Ions as a Highly Effective $\mathrm{Cs}^{+}$Remover. Angew Chemie Int Ed 53:7203-7208. https://doi.org/10.1002/anie.201402778

Datta SJ, Oleynikov P, Moon WK, Ma Y, Mayoral A, Kim H, Dejoie C, Song MK, Terasaki O, Yoon KB (2019) Removal of ${ }^{90} \mathrm{Sr}$ from Highly $\mathrm{Na}^{+}$-rich Liquid Nuclear Waste With a Layered Vanadosilicate. Energy Environ Sci 12:1857-1865. https://doi.org/10.1039/C8EE03302A

Davis ME (2014) Zeolites from a Materials Chemistry Perspective. Chem Mater 26:239245. https://doi.org/10.1021/cm401914u

El-Kamash AM (2008) Evaluation of Zeolite A for the Sorptive Removal of $\mathrm{Cs}^{+}$and $\mathrm{Sr}^{2+}$ Ions from Aqueous Solutions Using Batch and Fixed Bed Column Operations. J Hazard Mater 151:432-445. https://doi.org/10.1016/j.jhazmat.2007.06.009

El-Kamash AM, Zaki AA, El Geleel MA (2005) Modeling Batch Kinetics and Thermodynamics of Zinc and Cadmium Ions Removal from Waste Solutions Using Synthetic Zeolite A. J Hazard Mater 127:211-220. https://doi.org/10.1016/j.jhazmat.2005.07.021

Erdem E, Karapinar N, Donat R (2004) The Removal of Heavy Metal Cations by Natural Zeolites. J Colloid Interface Sci 280:309-314. https://doi.org/10.1016/j.jcis.2004.08.028

Fois E, Tabacchi G, Devaux A, Belser P, Brühwiler D, Calzaferri G, (2013) Host-Guest 
Interactions and Orientation of Dyes in the One-Dimensional Channels of Zeolite L. Langmuir 29:9188-9198. https://doi.org/10.1021/la400579w

Galletti C, Dosa M, Russo N, Fino D (2021) $\mathrm{Zn}^{2+}$ and $\mathrm{Cd}^{2+}$ Removal from Wastewater Using Clinoptilolite as Adsorbent. Environ. Sci. Pollut. Res. 28:24355-24361. https://doi.org/10.1007/s11356-020-08483-Z

Günay A, Arslankaya E, Tosun I (2007) Lead Removal from Aqueous Solution by Natural and Pretreated Clinoptilolite: Adsorption Equilibrium and Kinetics. J Hazard Mater 146:362-371. https://doi.org/10.1016/j.jhazmat.2006.12.034

Hincapie BO, Garces LJ, Zhang Q, Sacco A, Suib SL (2004) Synthesis of Mordenite Nanocrystals. Microporous Mesoporous 67:19-26. https://doi.org/10.1016/j.micromeso.2003.09.026

Ho YS, McKay G (1999a) Pseudo-Second Order Model for Sorption Processes. Process Biochem 34:451-465. https://doi.org/10.1016/S0032-9592(98)00112-5

Ho YS, McKay G (1999b) The Sorption of Lead(II) Ions on Peat. Water Res 33:578-584. https://doi.org/10.1016/S0043-1354(98)00207-3

Ibrahim HS, Jamil TS, Hegazy EZ (2010) Application of Zeolite Prepared from Egyptian Kaolin for the Removal of Heavy Metals: II. Isotherm Models. J Hazard Mater 182:842-847. https://doi.org/10.1016/j.jhazmat.2010.06.118

Hong M, Yu L, Wang Y, Zhang J, Chen Z, Dong L, Zan Q, Li R (2019) Heavy Metal Adsorption with Zeolites: The Role of Hierarchical Pore Architecture. Chem Eng J 359:363-372. https://doi.org/10.1016/j.cej.2018.11.087

Kwon S, Choi Y, Singh BK, Na K (2020) Selective and Rapid Capture of $\mathrm{Sr}^{2+}$ with LTA Zeolites: Effect of Crystal Sizes and Mesoporosity. Appl Surf Sci 506:145029. https://doi.org/10.1016/j.apsusc.2019.145029

Li J, Li M, Song Q, Wang S, Cui X, Liu F, Liu X (2020) Efficient Recovery of Cu(II) by LTA-zeolites with Hierarchical Pores and Their Resource Utilization in Electrochemical Denitrification: Environmentally Friendly Design and Reutilization of Waste in Water. J Hazard Mater 394:122554. https://doi.org/10.1016/j.jhazmat.2020.122554

Lobo RF (2003) Introduction to the Structural Chemistry of Zeolites. In: Auerbach SM, Carrado KA, Dutta PK (eds) Handbook of Zeolite Science and Technology. Marcel Dekker, pp 62-64.

Lu X, Wang F, Li X, Shih K, Zeng EY (2016) Adsorption and Thermal Stabilization of 
$\mathrm{Pb}^{2+}$ and $\mathrm{Cu}^{2+}$ by Zeolite. Ind Eng Chem Res 55:8767-8773. https://doi.org/10.1021/acs.iecr.6b00896

Marcus Y (1991) Thermodynamics of Solvation of Ions. Part 5.- Gibbs Free Energy of Hydration at 298.15 K. J Chem Soc Faraday Trans 87:2995-2999. https://doi.org/10.1039/FT9918702995

McCusker LB, Olson DH, Baerlocher C (2007) Atlas of Zeolite Framework Types. Elsevier, Amsterdam.

Mihaly-Cozmuta L, Mihaly-Cozmuta A, Peter A, Nicula C, Tutu H, Silipas D, Indrea E (2014) Adsorption of Heavy Metal Cations by Na-clinoptilolite: Equilibrium and Selectivity Studies. J Environ Manage 137:69-80. https://doi.org/10.1016/j.jenvman.2014.02.007

Moattar F, Hayeripour S (2004) Application of Chitin and Zeolite Adsorbents for Treatment of Low Level Radioactive Liquid Wastes. Int J Environ Sci Technol 1:45-50. https://doi.org/10.1007/BF03325815

Nightingale Jr ER (1959) Phenomenological Theory of Ion Solvation. Effective Radii of Hydrated Ions. J Phys Chem 63:1381-1387. https://doi.org/10.1021/j150579a011

Pham TCT, Docao S, Hwang IC, Song MK, Choi DY, Moon D, Oleynikov P, Yoon KB (2016) Capture of Iodine and Organic Iodides Using Silica Zeolites and the Semiconductor Behaviour of Iodine in a Silica Zeolite. Energy Environ Sci 9:10501062. https://doi.org/10.1039/C5EE02843D

Prajitno MY, Tangparitkul S, Zhang H, Harbottle D, Hunter TN (2021) The Effect of Cationic Surfactants on Improving Natural Clinoptilolite for the Flotation of $\begin{array}{llll}\text { Cesium. } & \text { J Hazard } & \text { Mater } & \end{array}$ https://doi.org/10.1016/j.jhazmat.2020.123567

Shen X, Qiu G, Yue C, Guo M, Zhang M (2017) Multiple Copper Adsorption and Regeneration by Zeolite 4A Synthesized from Bauxite Tailings. Environ Sci Pollut Res. https://doi.org/10.1007/s11356-017-9824-5

Sounthararajah DP, Loganathan P, Kandasamy J, Vigneswaran S (2015) Adsorptive Removal of Heavy Metals from Water Using Sodium Titanate Nanofibres Loaded onto GAC in Fixed-bed Columns. J Hazard Mater 287:306-316. https://doi.org/10.1016/j.jhazmat.2015.01.067

Sprynskyy M, Buszewski B, Terzyk AP, Namieśnik J (2006) Study of the Selection Mechanism of Heavy Metal $\left(\mathrm{Pb}^{2+}, \mathrm{Cu}^{2+}, \mathrm{Ni}^{2+}\right.$, and $\left.\mathrm{Cd}^{2+}\right)$ Adsorption on 
1 Clinoptilolite. J Colloid Interface $\quad$ Sci 304:21-28.

2 https://doi.org/10.1016/j.jcis.2006.07.068

3 Tashauoei HR, Attar HM, Amin MM, Kamali M, Nikaeen M, Dastjerdi MV (2010)

4 Removal of Cadmium and Humic Acid from Aqueous Solutions Using Surface

5 Modified Nanozeolite A. Int J Environ Sci Technol.

6 https://doi.org/10.1007/BF03326159

7 Wang S, Terdkiatburana T, Tadé MO (2008) Adsorption of $\mathrm{Cu}(\mathrm{II}), \mathrm{Pb}$ (II) and Humic

8 Acid on Natural Zeolite Tuff in Single and Binary Systems. Sep Purif Technol

9 62:64-70. https://doi.org/10.1016/j.seppur.2008.01.004

10 Zendelska A, Golomeova M, Blažev K, Krstev B, Golomeov B, Krstev A (2014) Kinetic

11 Studies of Zinc Ions Removal from Aqueous Solution by Adsorption on Natural

12 Zeolite. Int J Sci Environ Technol 3:1303-1318 


\section{Caption to Figures and Tables}

1 Fig. 1 Characterization of adsorbents, SEM image and XRD pattern of synthesized LTL 2 zeolite (a,b) and MOR zeolite (c,d).

3 Fig. 2 Plots of experimental data and kinetic modelling of the metal ion adsorption on 4 LTL zeolite including a) $\mathrm{Cs}^{+}$, b) $\mathrm{Pb}^{2+}$, c) $\mathrm{Cd}^{2+}$, d) $\mathrm{Sr}^{2+}$, e) $\mathrm{Cu}^{2+}$, f) $\mathrm{Zn}^{2+}$, g) pseudo-first5 order model, h) pseudo-second-order model with different period of adsorption time.

6 Fig. 3 Plots of experimental data and kinetic modelling of the metal ion adsorption on 7 MOR zeolite including a) $\mathrm{Cs}^{+}$, b) $\mathrm{Pb}^{2+}$, c) $\mathrm{Cd}^{2+}$, d) $\mathrm{Sr}^{2+}$, e) $\mathrm{Cu}^{2+}$, f) $\mathrm{Zn}^{2+}$, g) pseudo-first8 order model, h) pseudo-second-order model with different period of adsorption time.

9 Fig. 4 Metal ion adsorption in term of removal efficiency and adsorption capacity of metal ions on LTL zeolite ( $a$ and b) and MOR zeolite (c and d) with different initial concentration of metal ions.

Fig. 5 The adsorption modelling of metal ions on LTL (a, b) and MOR zeolite (c, d) with Langmuir isotherm model (a, c) and Freundlich isotherm model (b, d), respectively.

Table 1 Parameters of pseudo-first-order and pseudo-second-order models for the adsorption of $\mathrm{Cu}^{2+}, \mathrm{Cd}^{2+}, \mathrm{Pb}^{2+}, \mathrm{Zn}^{2+}, \mathrm{Cs}^{+}, \mathrm{Sr}^{2+}$ on LTL zeolite

Table 2 Parameters of pseudo-first-order and pseudo-second-order models for the adsorption of $\mathrm{Cu}^{2+}, \mathrm{Cd}^{2+}, \mathrm{Pb}^{2+}, \mathrm{Zn}^{2+}, \mathrm{Cs}^{+}, \mathrm{Sr}^{2+}$ on MOR zeolite

Table 3 Pseudo-second-order rate constant of the metal ion adsorption on synthesized LTL and MOR zeolites.

20 Table 4 EDS measurement data of $\mathrm{Pb}^{2+}$ saturated adsorbed on LTL and MOR zeolite.

21 Table 5 Ionic radius, hydrated radius and hydration energy of metal ions in this study.

22 Table 6 Parameters of Langmuir and Freundlich models for the adsorption of $\mathrm{Cu}^{2+}, \mathrm{Cd}^{2+}$, $23 \mathrm{~Pb}^{2+}, \mathrm{Zn}^{2+}, \mathrm{Cs}^{+}, \mathrm{Sr}^{2+}$ on LTL and MOR zeolite 
Fig. 1
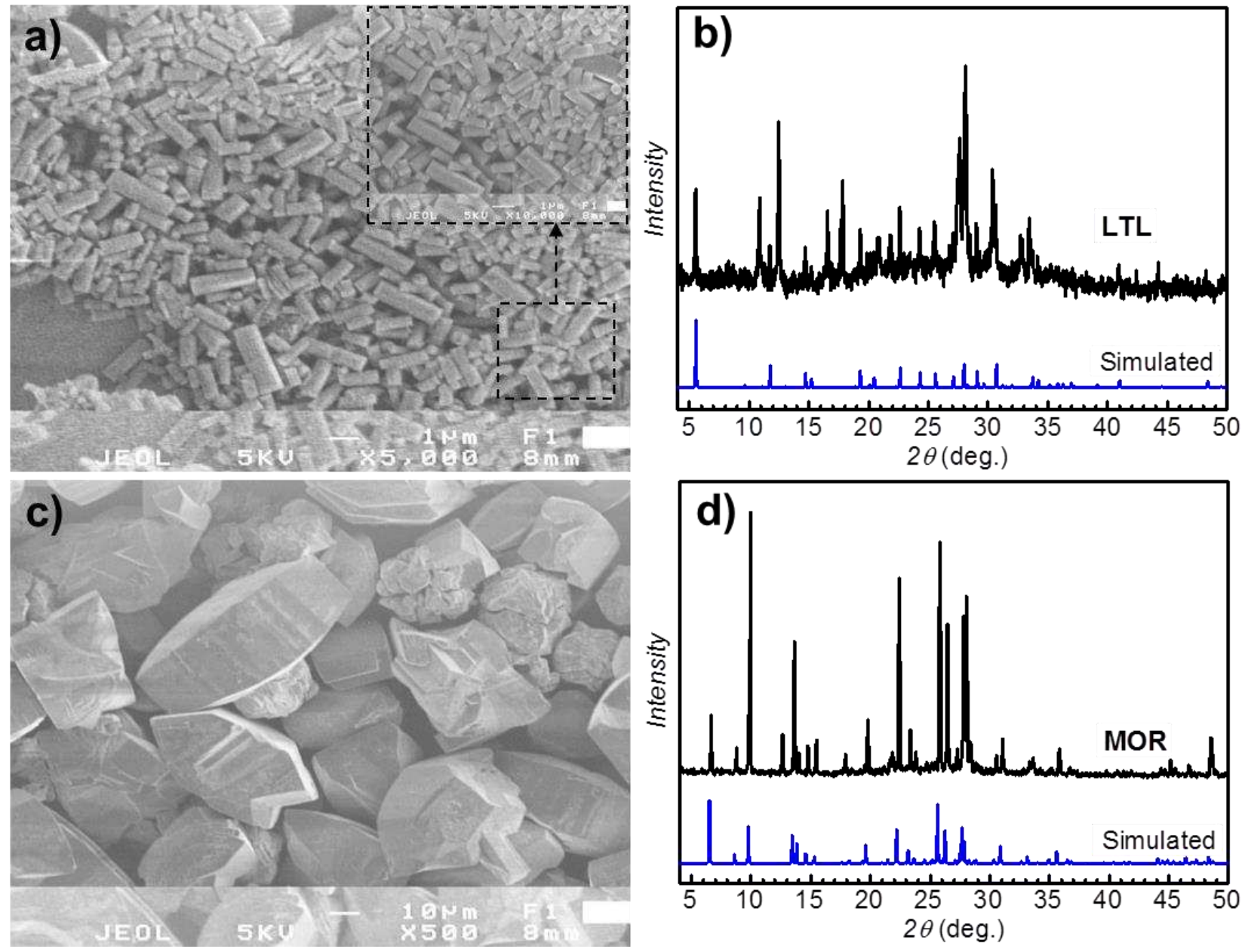
Fig. 2
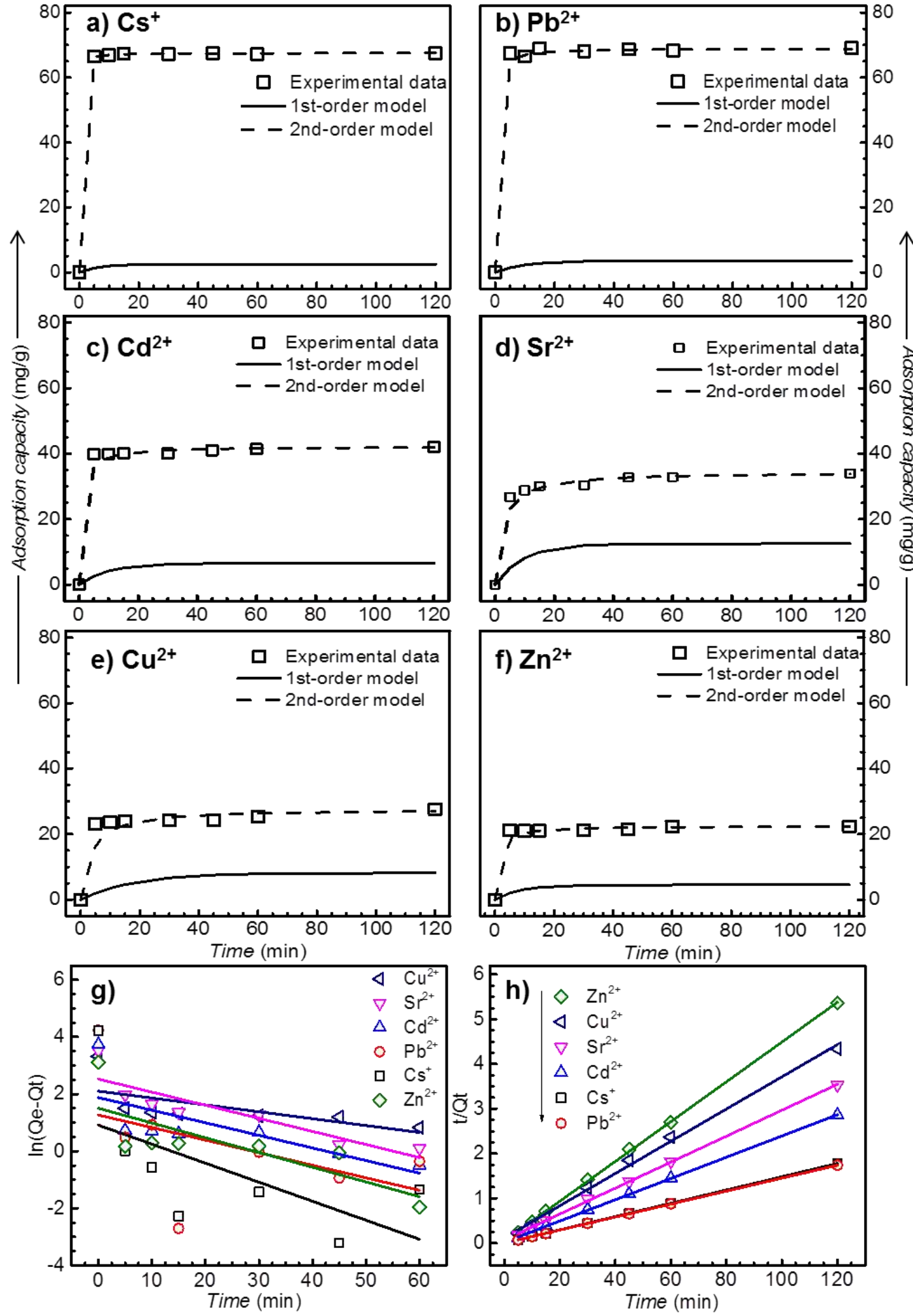
Fig. 3
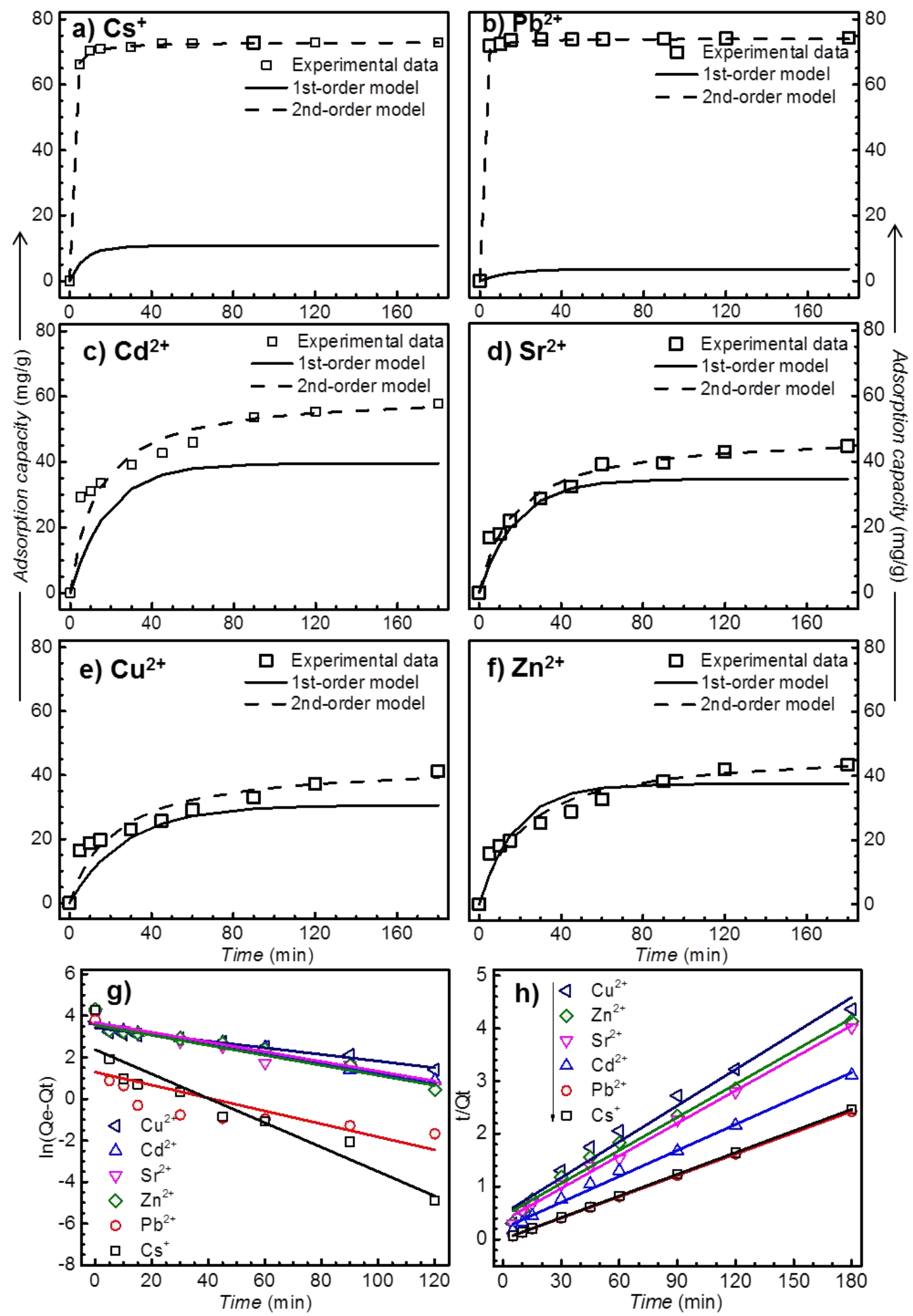
Fig. 4

a)
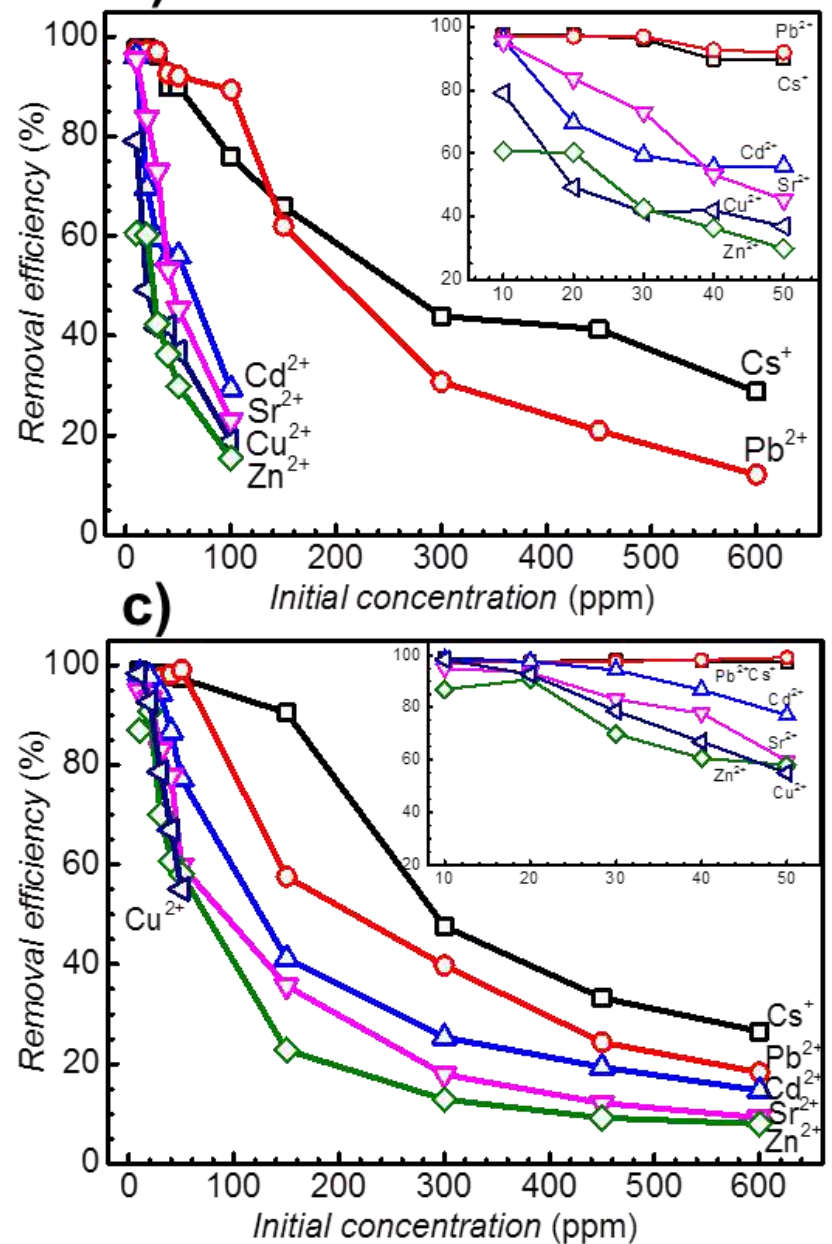

b)
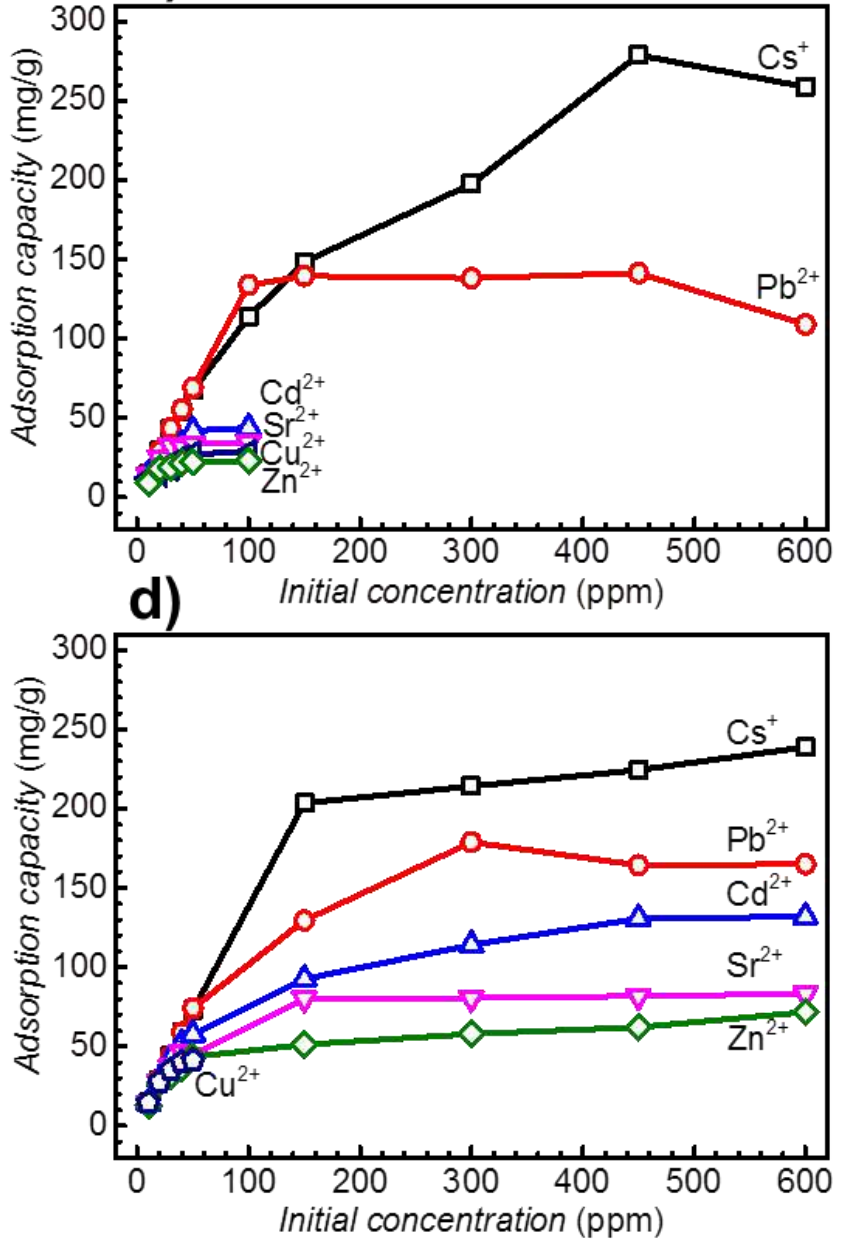
Fig. 5
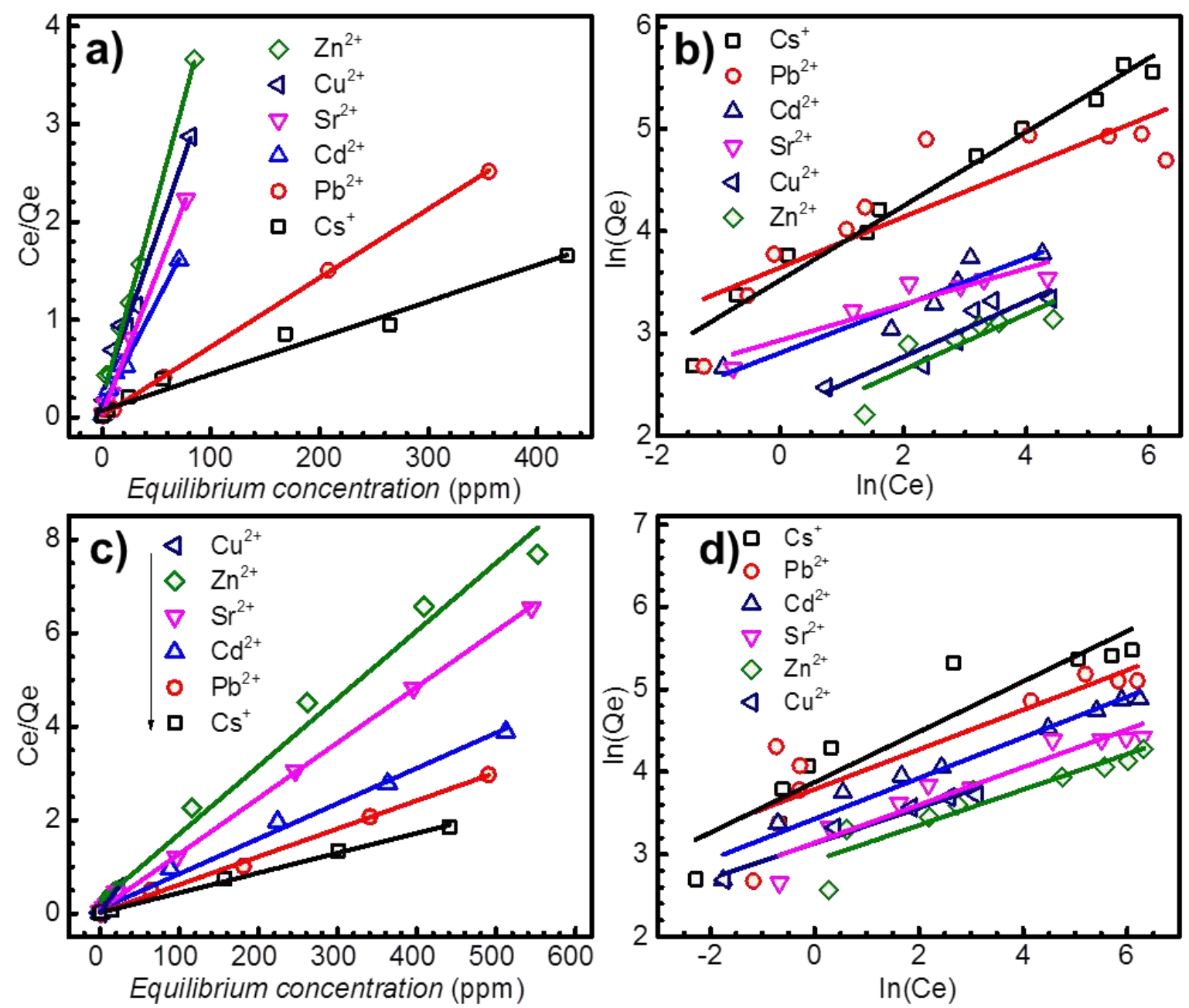
Table 1

\begin{tabular}{lcccccc}
\hline Metal ion & $\mathrm{Cu}^{2+}$ & $\mathrm{Cd}^{2+}$ & $\mathrm{Pb}^{2+}$ & $\mathrm{Zn}^{2+}$ & $\mathrm{Cs}^{+}$ & $\mathrm{Sr}^{2+}$ \\
\hline & Pseudo-first-order model & & & \\
\hline $\mathrm{q}_{\mathrm{es}}{ }^{(\mathrm{a})}(\mathrm{mg} / \mathrm{g})$ & 8.2 & 6.6 & 3.6 & 4.5 & 2.5 & 12.5 \\
$\mathrm{k}_{1}{ }^{(\mathrm{b})}(1 / \mathrm{min})$ & 0.056 & 0.102 & 0.101 & 0.119 & 0.153 & 0.105 \\
Correlation coefficient $\mathrm{R}^{2}$ & 0.4366 & 0.5227 & 0.2142 & 0.6047 & 0.3860 & 0.7871 \\
\hline \multicolumn{7}{c}{ Pseudo-second-order model } \\
$\mathrm{q}_{\mathrm{es}}{ }^{(\mathrm{a})}(\mathrm{mg} / \mathrm{g})$ & 27.8 & 42.2 & 69.0 & 22.5 & 67.6 & 34.5 \\
$\mathrm{k}_{2}{ }^{(\mathrm{c})}(\mathrm{g} / \mathrm{mg} . \min )$ & 0.0111 & 0.0281 & 0.0501 & 0.0407 & 0.1685 & 0.0120 \\
$\mathrm{Correlation}$ coefficient $\mathrm{R}^{2}$ & 0.9966 & 0.9999 & 1 & 0.9997 & 1 & 0.9995 \\
\hline $\mathrm{q}_{\mathrm{e}}{ }^{(\mathrm{d})}(\mathrm{mg} / \mathrm{g})$ & 27.6 & 42.0 & 69.1 & 22.4 & 67.5 & 34.0
\end{tabular}

$\left({ }^{a}\right)$ simulated equilibrium adsorption capacity, $\left({ }^{b}\right)$ pseudo-first sorption rate constant, $\left({ }^{c}\right)$ pseudo-second sorption rate constant, ${ }^{d}$ ) experimental adsorption capacity

Table 2

\begin{tabular}{|c|c|c|c|c|c|c|}
\hline Metal ion & $\mathrm{Cu}^{2+}$ & $\mathrm{Cd}^{2+}$ & $\mathrm{Pb}^{2+}$ & $\mathrm{Zn}^{2+}$ & $\mathrm{Cs}^{+}$ & $\mathrm{Sr}^{2+}$ \\
\hline \multicolumn{7}{|c|}{ Pseudo-first-order model } \\
\hline $\mathrm{q}_{\mathrm{es}}{ }^{(\mathrm{a})}(\mathrm{mg} / \mathrm{g})$ & 30.6 & 39.5 & 3.6 & 37.6 & 10.7 & 34.6 \\
\hline $\mathrm{k}_{1}^{(\mathrm{b})}(1 / \mathrm{min})$ & 0.037 & 0.054 & 0.072 & 0.056 & 0.135 & 0.056 \\
\hline Correlation coefficient $\mathrm{R}^{2}$ & 0.9538 & 0.9609 & 0.5017 & 0.9681 & 0.8843 & 0.9649 \\
\hline \multicolumn{7}{|c|}{ Pseudo-second-order model } \\
\hline $\mathrm{q}_{\mathrm{es}}{ }^{(\mathrm{a})}(\mathrm{mg} / \mathrm{g})$ & 43.9 & 61.0 & 74.1 & 48.1 & 73.0 & 48.5 \\
\hline $\mathrm{k}_{2}{ }^{(\mathrm{c})}(\mathrm{g} / \mathrm{mg} \cdot \min )$ & 0.0011 & 0.0013 & 0.0552 & 0.0010 & 0.0284 & 0.0012 \\
\hline Correlation coefficient $\mathrm{R}^{2}$ & 0.9774 & 0.9936 & 1 & 0.9884 & 1 & 0.9955 \\
\hline $\mathrm{q}_{\mathrm{e}}^{(\mathrm{d})}(\mathrm{mg} / \mathrm{g})$ & 41.3 & 57.8 & 74.3 & 43.6 & 73.0 & 44.8 \\
\hline
\end{tabular}


Table 3

\begin{tabular}{ccccccc}
\hline Zeolite & \multicolumn{5}{c}{ Rate constant $\mathbf{k}_{\mathbf{2}} \times \mathbf{1 0} \mathbf{3}$ (g/mg.min) } \\
\hline & $\mathrm{Pb}^{2+}$ & $\mathrm{Cu}^{2+}$ & $\mathrm{Cs}^{+}$ & $\mathrm{Sr}^{2+}$ & $\mathrm{Zn}^{2+}$ & $\mathrm{Cd}^{2+}$ \\
\hline LTL & 50.1 & 11.1 & 168.5 & 12 & 40.7 & 28.1 \\
MOR & 55.2 & 1.1 & 28.4 & 1.2 & 1.0 & 1.3 \\
\hline
\end{tabular}

Table 4

\begin{tabular}{ccccc}
\hline \multirow{2}{*}{ Element } & \multicolumn{2}{c}{ LTL zeolite (Atomic\%) } & \multicolumn{2}{c}{ MOR zeolite (Atomic\%) } \\
\cline { 2 - 5 } & $\begin{array}{c}\text { Before } \\
\text { adsorption }\end{array}$ & $\begin{array}{c}\text { After } \\
\text { adsorption }\end{array}$ & $\begin{array}{c}\text { Before } \\
\text { adsorption }\end{array}$ & $\begin{array}{c}\text { After } \\
\text { adsorption }\end{array}$ \\
\hline $\mathbf{O}$ & 69.23 & 63.37 & 68.86 & 69.03 \\
$\mathbf{A l}$ & 6.25 & 7.99 & 3.45 & 3.86 \\
$\mathbf{S i}$ & 18.57 & 22.18 & 23.83 & 25.18 \\
$\mathbf{K}$ & 5.95 & 4.74 & - & - \\
$\mathbf{N a}$ & - & - & 3.86 & 0 \\
$\mathbf{P b}$ & 0 & 1.72 & 0 & 1.93 \\
\hline
\end{tabular}

Table 5

\begin{tabular}{cccc}
\hline Metal ion & $\begin{array}{c}\text { Ionic radius } \\
\text { (Nightingale Jr 1959) } \\
(\mathrm{nm})\end{array}$ & $\begin{array}{c}\text { Hydrated radius } \\
\text { (Nightingale Jr 1959) } \\
(\mathrm{nm})\end{array}$ & $\begin{array}{c}\text { Hydration energy } \\
\text { (Marcus 1991) } \\
(\mathrm{kJ} / \mathrm{mol})\end{array}$ \\
\hline $\mathrm{Cs}^{+}$ & 0.169 & 0.329 & -245 \\
$\mathrm{~Pb}^{2+}$ & 0.132 & 0.410 & $-1,345$ \\
$\mathrm{Sr}^{2+}$ & 0.113 & 0.412 & $-1,385$ \\
$\mathrm{Cu}^{2+}$ & 0.072 & 0.419 & $-1,920$ \\
$\mathrm{Cd}^{2+}$ & 0.097 & 0.426 & $-1,575$ \\
$\mathrm{Zn}^{2+}$ & 0.074 & 0.430 & $-1,880$ \\
\hline
\end{tabular}


Table 6

\begin{tabular}{lcccccc}
\hline \multicolumn{1}{c}{ Metal ion } & $\mathrm{Cu}^{2+}$ & $\mathrm{Cd}^{2+}$ & $\mathrm{Pb}^{2+}$ & $\mathrm{Zn}^{2+}$ & $\mathrm{Cs}^{+}$ & $\mathrm{Sr}^{2+}$ \\
\hline \multicolumn{7}{c}{ LTL zeolite } \\
\hline $\mathrm{Q}^{0}(\mathrm{mg} / \mathrm{g})^{(\mathrm{a})}$ & 30.9 & 47.2 & 142.9 & 24.4 & 270.3 & 35.0 \\
$\mathrm{~K}_{\mathrm{L}}(1 / \mathrm{g})^{(\mathrm{b})}$ & 0.141 & 0.182 & 0.372 & 0.233 & 0.051 & 1.007 \\
$\mathrm{R}_{\mathrm{L}}{ }^{(\mathrm{c})}$ & 0.0663 & 0.0520 & 0.0045 & 0.0411 & 0.0304 & 0.0098 \\
$\mathrm{R}^{2}$ & 0.9841 & 0.9842 & 0.9998 & 0.9975 & 0.9804 & 0.9997 \\
\hline \multicolumn{7}{c}{ Freundlich model } \\
\hline $1 / \mathrm{n}(\mathrm{d})$ & 0.27 & 0.23 & 0.25 & 0.27 & 0.36 & 0.18 \\
$\mathrm{~K}_{\mathrm{F}}(\mathrm{mg} / \mathrm{g}){ }^{(\mathrm{e})}$ & 9.29 & 16.82 & 38.32 & 8.13 & 33.89 & 18.82 \\
$\mathrm{R}^{2}$ & 0.8675 & 0.8956 & 0.7558 & 0.7271 & 0.9748 & 0.8533 \\
$\mathrm{q}_{\max }{ }^{(\mathrm{f})}(\mathrm{mg} / \mathrm{g})$ & 28.3 & 43.9 & 141.4 & 23.1 & 278.8 & 34.6 \\
\hline
\end{tabular}

MOR zeolite

\begin{tabular}{lcccccc}
\hline \multicolumn{7}{c}{ Langmuir model } \\
\hline $\mathrm{Q}^{0}(\mathrm{mg} / \mathrm{g})^{(\mathrm{a})}$ & 42.4 & 133.3 & 166.7 & 69.0 & 232.6 & 84.0 \\
$\mathrm{~K}_{\mathrm{L}}(1 / \mathrm{g})^{(\mathrm{b})}$ & 1.35 & 0.08 & 0.35 & 0.06 & 0.23 & 0.14 \\
$\mathrm{R}_{\mathrm{L}}{ }^{(\mathrm{c})}$ & 0.0146 & 0.0205 & 0.0047 & 0.0284 & 0.0071 & 0.0118 \\
$\mathrm{R}^{2}$ & 0.9986 & 0.9942 & 0.9982 & 0.9876 & 0.9983 & 0.9995 \\
\hline \multicolumn{7}{c}{ Freundlich model } \\
\hline $1 / \mathrm{n}(\mathrm{d})$ & 0.21 & 0.25 & 0.24 & 0.22 & 0.31 & 0.23 \\
$\mathrm{~K}_{\mathrm{F}}(\mathrm{mg} / \mathrm{g})^{(\mathrm{e})}$ & 22.92 & 30.85 & 44.16 & 18.55 & 48.10 & 23.12 \\
$\mathrm{R}^{2}$ & 0.9666 & 0.9635 & 0.7698 & 0.8682 & 0.8822 & 0.9138 \\
$\mathrm{q}_{\max }{ }^{(\mathrm{f})}(\mathrm{mg} / \mathrm{g})$ & 41.3 & 131.9 & 178.9 & 71.8 & 238.8 & 83.3 \\
\hline
\end{tabular}

${ }^{(a)}$ monolayer adsorption capacity, ${ }^{(b)}$ Langmuir constant, ${ }^{(c)}$ equilibrium parameter, ${ }^{(d)}$ sorption intensity constant, ${ }^{(e)}$ Freundlich constant, ${ }^{(f)}$ experimental maximum adsorption capacity 